\title{
To Assess the Intraoperative Complications in Small Incision Cataract Surgery and Visual Outcome
}

\section{Smita Kunwar ${ }^{1 *}$, Janak Poudel ${ }^{2}$ and Dr. Jyoti Kattige ${ }^{3}$}

${ }^{1}$ B. Optom Vittala International Institute of Ophthalmology, Bangalore, India

${ }^{2}$ B. Optom, Vittala International Institute of Ophthalmology Bangalore, India

${ }^{3}$ Consultant Ophthalmologist, Fellowship in Glaucoma, Bangalore, India

*Corresponding Author: Janak poudel B.Optom, Vittala International Institute of

Ophthalmology, Bangalore, India.

DOI: 10.31080/ASOP.2020.03.0154
Received: July 14, 2020

Published: July 28, 2020

(C) All rights are reserved by Janak Poudel., et al.

\begin{abstract}
Background and Objective: Small incision cataract surgical procedure is the most normally performed surgical treatment for cataract in growing countries. This system is safe and effective to boom the output of cataract surgical services, at the identical time affordable. The present have a look at is undertaken to recognize the prevalence of intraoperative complications and how exceptional the complications may be minimized and dealt with and additionally its visual outcome.

Method: A general of 471 instances turned into studied. Intraoperative complications have been studied and managed. Visual outcome following these complications have been studied with the aid of noting the BCVA after 1st week and 6th week of surgical treatment.

Results: Out of 471 patients, 52(11\%) patients The intraoperative complications were posterior capsular rupture occurred in 29 patients (55.8\%), iris prolapse in 18 patients (34.6\%), premature entry in 6 patients (11.5\%), iridodialysis in 1 patient (1.9\%), zonular dialysis in 1 patients (1.9\%). 52 patients who had intraoperative problem came for follow up till sixth weeks, 28 cases (53.8\%) had post-operative BCVA 6/9 or higher in 1st week and 24 cases had post-operative BCVA 6/18 or worse in 1 st week. In 6 th week 42 patients $(80.8 \%)$ had $6 / 9$ or better and 10 patients $(19.2 \%)$ had $6 / 18$ or worse.

Interpretation and Conclusion: Small incision cataract surgical operation is top approach which gives early and top visual outcomes. Overall the complication of small incision cataract surgery is less.

Keywords: Small Incision Cataract Surgery; Intraoperative Complications; Visual Outcome
\end{abstract}

\section{Abbreviations}

AC-IOL: Anterior Chamber Intraocular Lens; BCVA: Best Corrected Visual Acuity; CTR: Capsular Tension Ring; CCC: Circumcorneal Congestion; CF: Counting Finger; CME: Cystoid Macular Edema; DCT: Dacryocystectomy; DCR: Dacryocystorhinostomy; ECG: Electrooculogram; ERG: Electroretinogram; ECD: Endothelial Cell Density; HM: Hand Movement; HMSC: Hypermature Senile Cataract; ISC: Immature Senile Cataract; IOL: Intraocular Lens; IFIS: Intraoperative Floppy Iris Syndrome; K: Keratometry; KPs: Keratic Precipitates; LI: Laser Interferometry; MSC: Mature Senile Cataract; Mg: Milligram; Mm: Millimeter; NSAIDS: Non-steroidal Anti- inflammatory Drugs; PL+: Perception of Light; PC-IOL: Posterior Chamber Intraocular Lens; PCR: Posterior Capsular Rupture; PAM: Potential Acuity Meter; PR: Projection of Light Ray; RAPD: Relative Afferent Pupillary Defect; UCVA: Uncorrected Visual Acuity; VA: Visual Acuity; VER: Visually Evoked Response

\section{Introduction}

The lens is a transparent, biconvex, elliptical, semisolid, avascular body of crystalline appearance positioned among the iris and the vitreous measuring about $10 \mathrm{~mm}$ in diameter and $4 \mathrm{~mm}$ thick. Cataract refers to development of any opacity within the lens or its capsule which leads in lower in vision. Age related cataracts are responsible for $51 \%$ of world blindness [1-3].

Cataract surgery involves removal of the natural lens of eye which has been opacified, and its replacement with an artificial intraocular lens. There are mainly two types of cataract surgery: first Intraocular cataract extraction (ICCE) and second Extracapsular cataract extraction (ECCE). There are different techniques of extracapsular cataract extraction, they are: conventional extracapsular extraction (ECCE), manual small incision cataract surgery (SICS) and phacoemulsification. 
Small incision cataract surgical procedure is the most normally performed surgical treatment for cataract in growing countries. This system is safe and effective to boom the output of cataract surgical services, at the identical time affordable. Small incision cataract surgery usually results in a good visual outcome and is useful for high volume cataract surgery. SICS is also known as the selfsealing sutureless wound surgery.

Although it has many advantages there are few complications of this technique. They are as follows:

- Superior rectus muscle laceration

- $\quad$ Excessive bleeding

- Descemet's detachment takes place due to defective instrumentations which include keratome or a chunk of razor blade

- Iridodialysis

- $\quad$ Posterior capsular rupture (PCR)

- Vitreous loss

- $\quad$ Nucleus drop

- Iris prolapse

- Zonular Dialysis [5-7].

\section{Objectives of the Study}

The present study has the following objectives:

- To study the intraoperative complications of small incision cataract surgical operation and it's management.

- To study the visual outcome following the management of intraoperative complications.

\section{Methodology}

Study design: Prospective study.

Sample size: 52 eye with considerable cataract which satisfy the inclusion criteria.

Place of study: Vittala International Institute of Ophthalmology,

Bangalore, India.

Inclusion criteria

- $\quad$ Patient among 40 - 80 years of age.

- Patient confirmed to have significant cataract.

- Patient undergoing Small Incision Cataract Surgery.

\section{Exclusion criteria}

- Subluxation or dislocation of lens.

- Patient with complicated cataract, traumatic cataract, pre-existing zonular weakness.

- Other ocular pathologies like corneal opacity, uveitis etc.

- Severe dry eye syndrome with corneal erosion.

- Condition affecting macula and retinal pathologies.

Study parameter

- Visual acuity assessment was done by using Snellen chart and measurement of uncorrected distance visual acuity, best corrected vision were noted.

- Slit lamp biomicroscopy examination of anterior segment to assess the cornea, anterior chamber, pupil, types of cataract and grading of nucleus were done. Nucleus grading was done using Lens Opacity Classification system (LOCS).

- Intraocular pressure was checked by perkin's applanation tonometer.

- $\quad$ Detailed fundus examination was performed by indirect ophthalmoscope.

- $\quad$ Keratometry model BL and biometry was done for calculation of IOP power.

- Patient is counseled for small incision cataract surgery.

- Informed consent was taken from patients before surgery.

\section{Statistical analysis}

Data analysis was performed by using SPSS (Statistical package for social science) version 20.0.

P-value $<0.05$ consider as significant.

Formula used for 1 proportion:

$\mathrm{n}=\left(\frac{z_{\alpha / 2}}{d}\right)^{2} \mathrm{p}(1-\mathrm{p})$ 


\begin{tabular}{|c|c|c|c|}
\hline Alpha & $\mathbf{0 . 0 5}$ & $\mathrm{Z}=\mathbf{- 1 . 9 5 9 9 6 3 9 8 4 5 4 0 0 5}$ & $\begin{array}{c}\text { Sample } \\
\text { required }\end{array}$ \\
\hline $\mathrm{d}$ & 0.06 & & 51.37682441 \\
\hline $\mathrm{p}$ & 0.05072 & & Sample Required \\
\hline $1-\mathrm{p}$ & 0.94928 & & 52 \\
\hline
\end{tabular}

Table

Results

\begin{tabular}{|l|c|c|c|}
\hline & & Count & Column N \% \\
\hline Gender & Male & 22 & $42.30 \%$ \\
\hline & Female & 30 & $57.70 \%$ \\
\hline
\end{tabular}

Table 1: Gender distribution of patients studied.

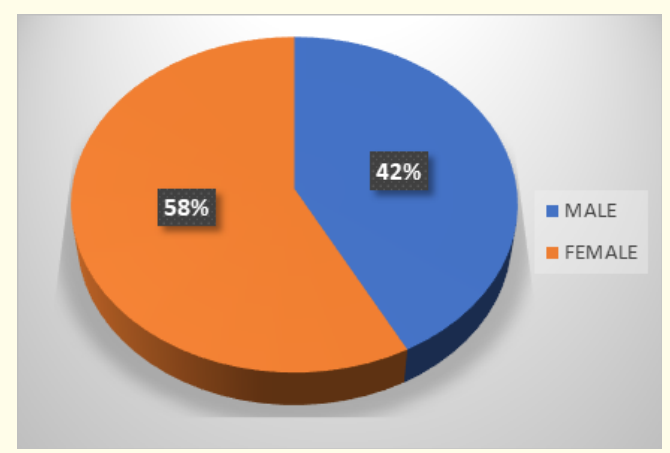

Figure 1: Graphical representation of gender distribution.

In our study, out of 52 patients studied 22 patients $(42.30 \%)$ were females and the rest 30 patients $(57.70 \%)$ were male.

\begin{tabular}{|c|c|c|}
\hline Eye & Frequency & Percentage \% \\
\hline Right Eye & 26 & 50 \\
\hline Left Eye & 26 & 50 \\
\hline Total & 52 & 100 \\
\hline
\end{tabular}

Table 2: Eye involved in patients studied.

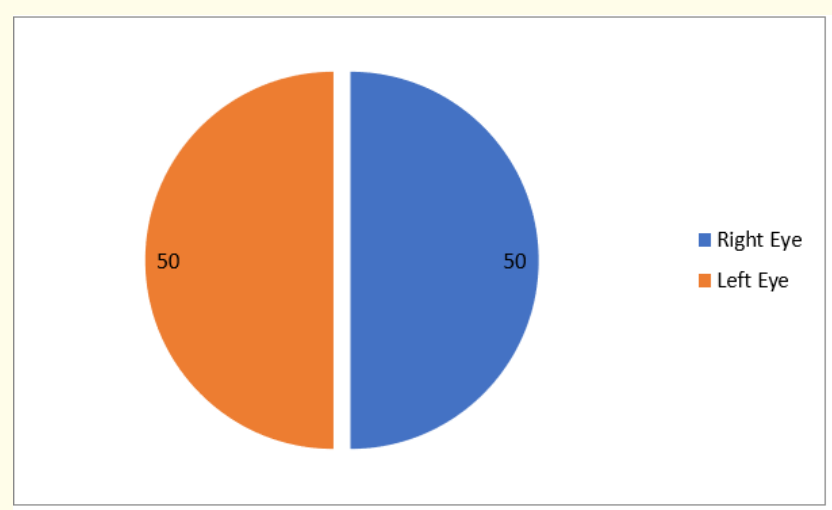

Figure 2: Graphical representation of laterality of cataract.
In our study out of 52 eyes studied, 26 eyes (50\%) were right eye and 26 eyes (50\%) were left eyes. Both eyes can get affected with cataract with equal possibilities.

\begin{tabular}{|c|c|c|}
\hline & Number & Percent \\
\hline Total surgeries & 471 & 100 \\
\hline Total complications & 52 & 11.04034 \\
\hline No Complication & 419 & 88.95966 \\
\hline
\end{tabular}

Table 3: Percentage of intraoperative complication.

In our study 471 number of surgery were done out of which 52 number of surgery got intraoperative complication and 419 number of surgery without intraoperative complications.

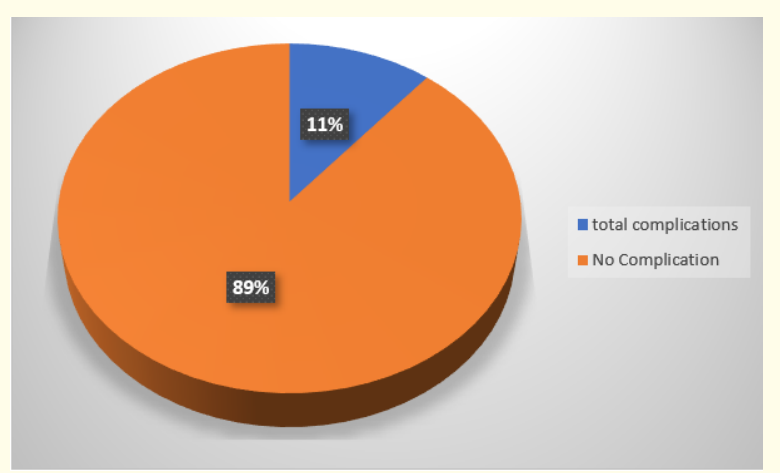

Figure 3: Graphical representation of percentage of cataract.

In our study out of 471 surgery (100\%), 419 surgery (89\%) were no intraoperative complication arises and in 52 surgery (11\%) were intraoperative complication arises.

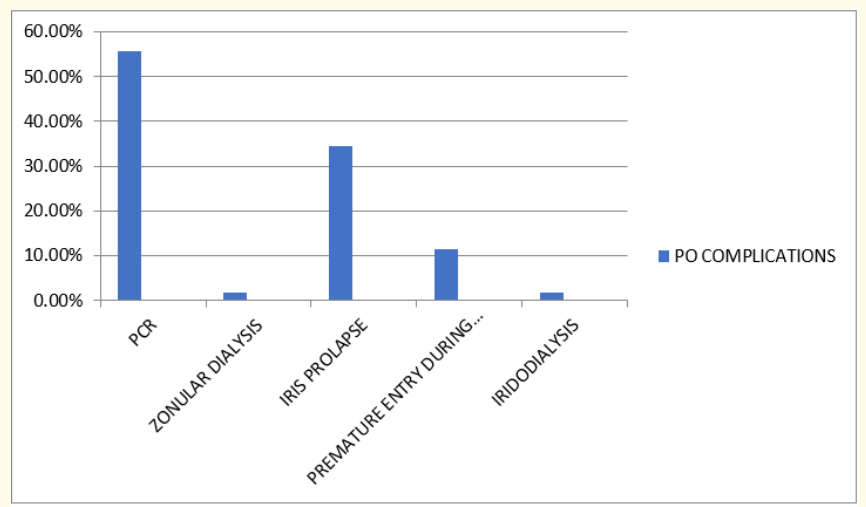

Figure 4: Graphical representation of Intraoperative complication during SICS. 


\begin{tabular}{|l|c|c|}
\hline \multicolumn{1}{|c|}{ Complication } & Count & Column N\% \\
\hline PCR & 29 & $55.8 \%$ \\
\hline Zonular dialysis & 1 & $1.9 \%$ \\
\hline Iris prolapse & 18 & $34.6 \%$ \\
\hline $\begin{array}{l}\text { Premature entry during wound } \\
\text { construction }\end{array}$ & 6 & $11.5 \%$ \\
\hline Iridodialysis & 1 & $1.9 \%$ \\
\hline
\end{tabular}

Table 4: Intraoperative complication.

Out of 52 patients (11\%) who had intraoperative complication, PCR occurred in 29 patients (55.8\%), iris prolapse occurs in 18 patients (34.6\%), premature entry during wound construction occurs in 6 patients (11.5\%), iridodialysis and zonular dialysis is a rare complication which occurs in 1 patient (1.9\%).

In our study 52 surgery (11\%) who got intraoperative complications were managed by the following process: 30 patients $(57.7 \%)$ were managed by anterior vitrectomy, for 1 patient (1.9\%) ECR were used, iris reposition in 18 patients (34.6\%) and suturing of wound in 22 patient (42.3\%) were done.

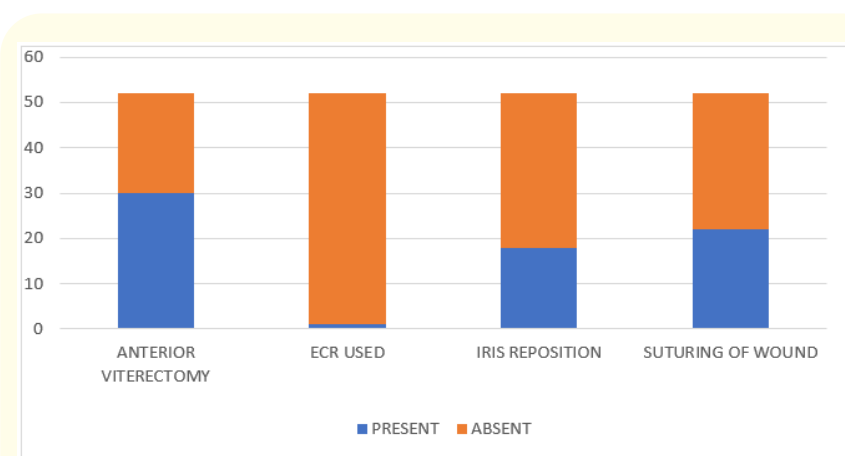

Figure 5: Graphical representation of management of intraoperative complications.

\begin{tabular}{|c|c|c|}
\hline Visual acuity & No. & \% \\
\hline Less than $6 / 60$ & 40 & 76.9 \\
\hline $6 / 60-6 / 36$ & 6 & 11.5 \\
\hline Better than 6/36 & 6 & 11.5 \\
\hline Total & 52 & 100 \\
\hline
\end{tabular}

Table 6: Preoperative best corrected visual acuity.

Out of 471 cases, 52 cases who had intraoperative complication came for follow up till $6^{\text {th }}$ weeks, 28 cases (53.8\%) had postoperative BCVA $6 / 9$ or better in $1^{\text {st }}$ week and 24 cases (46.2) had

\begin{tabular}{|l|c|c|c|}
\hline \multirow{2}{*}{ PO BCVA $1^{\text {st }}$ week } & $6 / 9$ or better & 28 & $53.8 \%$ \\
\cline { 2 - 4 } & $6 / 18$ or worse & 24 & $46.2 \%$ \\
\hline \multirow{2}{*}{ PO BCVA Week 6 } & $6 / 9$ or better & 42 & $80.8 \%$ \\
\cline { 2 - 4 } & $6 / 18$ or worse & 10 & $19.2 \%$ \\
\hline
\end{tabular}

Table 7: BCVA in 1 week and $6^{\text {th }}$ week.

post-operative BCVA $6 / 18$ or worse in $1^{\text {st }}$ week. In post-operative. BCVA in $6^{\text {th }}$ week 42 cases $(80.8 \%)$ has $6 / 9$ or better and 10 cases $(19.2 \%)$ had $6 / 18$ or worse.

\begin{tabular}{|c|c|c|c|c|c|}
\hline \multicolumn{6}{|c|}{ PO BCVA $1^{\text {st }}$ Week* PO BCVA Week6 Cross tabulation } \\
\hline & & & \multicolumn{2}{|c|}{ PO BCVA Week 6} & \multirow[b]{2}{*}{ Total } \\
\hline & & & $\begin{array}{l}6 / 9 \text { or } \\
\text { better }\end{array}$ & $\begin{array}{c}\text { 6/18 or } \\
\text { worse }\end{array}$ & \\
\hline \multirow{6}{*}{$\begin{array}{l}\text { PO BCVA } \\
1^{\text {st }} \text { week }\end{array}$} & \multirow{3}{*}{$\begin{array}{l}6 / 9 \text { or } \\
\text { better }\end{array}$} & Count & 28 & 0 & 28 \\
\hline & & $\begin{array}{c}\% \text { within PO } \\
\text { BCVA } 1^{\text {st }} \text { week }\end{array}$ & $100.0 \%$ & $0.0 \%$ & $100.0 \%$ \\
\hline & & $\begin{array}{c}\text { \% within PO } \\
\text { BCVA Week } 6\end{array}$ & $66.7 \%$ & $0.0 \%$ & $53.8 \%$ \\
\hline & \multirow{3}{*}{$\begin{array}{c}6 / 18 \text { or } \\
\text { worse }\end{array}$} & Count & 14 & 10 & 24 \\
\hline & & $\begin{array}{c}\% \text { within PO } \\
\text { BCVA } 1^{\text {st }} \text { week }\end{array}$ & $58.3 \%$ & $41.7 \%$ & $100.0 \%$ \\
\hline & & $\begin{array}{c}\% \text { within PO } \\
\text { BCVA Week } 6\end{array}$ & $33.3 \%$ & $100.0 \%$ & $46.2 \%$ \\
\hline \multicolumn{2}{|l|}{ Total } & Count & 42 & 10 & 52 \\
\hline \multicolumn{2}{|c|}{$\begin{array}{l}\% \text { within PO } \\
\text { BCVA } 1^{\text {st }} \text { week }\end{array}$} & $80.8 \%$ & $19.2 \%$ & $100.0 \%$ & \\
\hline \multicolumn{2}{|c|}{$\begin{array}{l}\% \text { within PO } \\
\text { BCVA Week } 6\end{array}$} & $100.0 \%$ & $100.0 \%$ & $100.0 \%$ & \\
\hline \multicolumn{6}{|c|}{ P Value $<0.001$} \\
\hline
\end{tabular}

Table 8: Comparison of $1^{\text {st }}$ week and week 6.

14 individuals who had $6 / 18$ or worse in the $1^{\text {st }}$ week had improved to $6 / 9$ or better in week 6 and is a significant change with a $\mathrm{p}$ value of $<0.001$.

\section{Discussion}

Small incision cataract surgery is most commonly performed and a promising method of treatment for cataract. Many previous studies showed improvement in visual acuity from small incision cataract surgery. We have conducted the study with the aim to determine the visual outcome along with the intraoperative complications of small incision cataract surgery. 


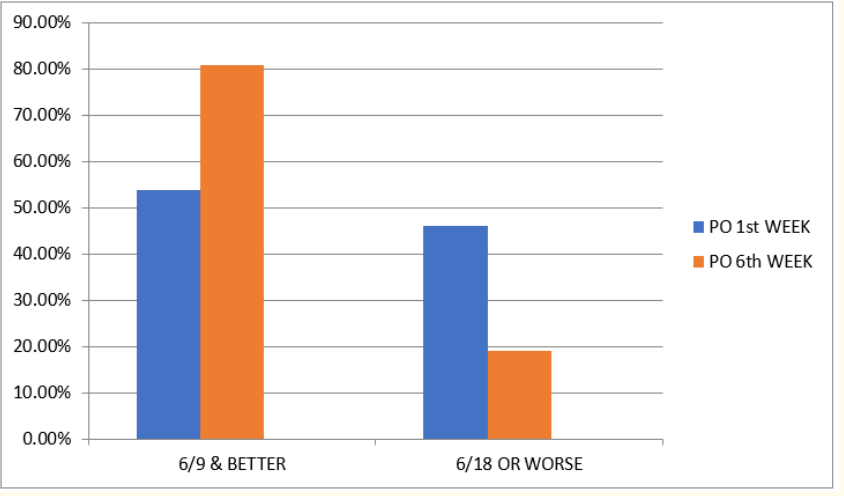

Figure 6: Graphical representation of Post-operative BCVA $1^{\text {st }}$ week and in 6 week. The above bar chart represent the changes in mean BCVA at 1 st week and $6^{\text {th }}$ week of post-operative followup. There is significant improvement at $1^{\text {st }}$ week and $6^{\text {th }}$ week of post-operative period.

In our study 52 cases who had intraoperative complication came for follow up till $6^{\text {th }}$ weeks. In post-operative follow up the BCVA in $6^{\text {th }}$ week of 42 cases $(80.8 \%)$ was $6 / 9$ or better and 10 cases $(19.2 \%)$ had $6 / 18$ or worse.

Hosamani SA., et al. [13] in 2013 found that at the end of $6^{\text {th }}$ week of surgery BCVA was 6/12 on snellen's chart.

Similarly, Mrunal Patil., et al. [12] in 2016 in their study, found that $214(85.6 \%)$ patients had BCVA $6 / 6$ at the end of $6^{\text {th }}$ week as well as $25(10 \%)$ patients had 6/9 improvement. The intraoperative complications were seen in a total of $22(88 \%)$ patients which included PCR in 6 eyes (2.4\%), iris prolapse in 5 eyes (2\%), zonular dialysis in 2 eyes $(0.8 \%)$, and superior iridodialysis in 1 eye $(0.4 \%)$

Similarly, Richard Daniel., et al. [14] in 1990 in their study they found that $81 \%$ of the patients attained $6 / 18$ vision or better at the end of $6^{\text {th }}$ week of follow up after surgery. Along with that they found that the Accidental rupture of the posterior capsule occurred in $70 \%$ of the patients as well as rate of vitreous loss was also found to be $6.1 \%$.

In our study we observed that the Posterior capsular rupture complication was higher in comparision to other complications. For the management of PCR complication anterior vitrectomy was performed, Iris reposition and suturing was done to manage the iris prolapse and surgical repair of dialysis was done for iridodialysis. Suturing of wound using 10-0 nylon was performed to manage the premature entry. ECR were used and anterior vitrectomy was performed to manage Zonular dialysis.

\section{Conclusion}

Cataract surgery in eyes with SICS has lower incidence of intraoperative complication. Posterior capsular rupture and iris prolapse were the most common intraoperative complications compared to zonular dialysis, iridodialysis, premature entry observed in our study. SICS gives post-operative BCVA of $6 / 9$ or better in a greater proportion of patients. A complete preoperative workup helps reduce intraoperative complications and maximizes the postoperative results.

\section{Limitations of the Study}

Vision was assessed only with Snellen chart. The vision is compared between $1^{\text {st }}$ and $6^{\text {th }}$ week only, $2^{\text {nd }} 3^{\text {rd }} 4^{\text {th }}$ and $5^{\text {th }}$ week vision has not compared.

\section{Bibliography}

1. Koch P S. "Structural analysis of cataract incision construction". Journal of Cataract and Refractive Surgery 17 (1991): 66-67.

2. Copyright(C)2007, 2003, 1996, A K khurana, Published by New Age International (P) Ltd, Publishers.

3. Laura Sminkey. Prevention of Blindness and Visual impairment World Health Organization (2015).

4. The global blindness of dense 2014: Geneva, Switzerland: World Health Organization (2008).

5. Taguri A H and Sanders R. "Iris prolapse in Small Incision Cataract Surgery". Ophthalmic Surgery, Lasers and Imaging Retina 33.1 (2002): 66-70.

6. Cionni R J and Osher R H. "Management of profound zonular dialysis or weakness with a new endocapsular ring designed for scleral fixation". Journal of Cataract and Refractive Surgery 24.10 (1998): 1299-1306.

7. Gimbal H V and Sun R. "Clinical applications of capsular tension rings in cataract surgery". Ophthalmic Surgery, Lasers and Imaging Retina 33.1 (2002): 44-53.

8. Shrikanth Shetty A., et al. "A study of intraoperative complications of Manual Small Incision Cataract surgery and it's visual outcome" (2004).

9. Hashemi Hassan., et al. "A study on intraoperative complications of cataract surgery in Tehran Province, Iran" (2016). 
10. Ramesh Chandra Bhatta., et al. "Outcome of Manual Small Incision Cataract at the base hospital and improved surgical eye camps in Nepal". Journal of Clinical and Experimental Ophthalmology (2011).

11. Lummen P., et al. "Evaluated the risk factors for intraoperative complication" (1990).

12. Mrunal Suresh Patil., et al. "Study on intraoperative complications in Small Incision Cataract Surgery, its management and visual outcome". MVP Journal of Medical Sciences 3.1 (2016).

13. Sushna A Hosamani., et al. "Efficacy of Small Incision Cataract Surgery in hospital based eye camp in North Karnataka”. Journal of Clinical Ophthalmology and Research 2.1 (2013): 13-14.

14. Richard Daniel., et al. "Evaluation of visual outcome of cataract surgery in an Indian camp” (1990).

\section{Assets from publication with us}

- Prompt Acknowledgement after receiving the article

- Thorough Double blinded peer review

- Rapid Publication

- Issue of Publication Certificate

- High visibility of your Published work

Website: www.actascientific.com/

Submit Article: www.actascientific.com/submission.php

Email us: editor@actascientific.com

Contact us: +919182824667 